\title{
Parental Support, Self-Efficacy Beliefs, Outcome Expectations and Interests in Science, Technology, Engineering and Mathematics (STEM) ${ }^{*}$
}

\section{Apoyo parental, creencias de autoeficacia, resultados esperados e intereses en Ciencia, Tecnología, Ingeniería y Matemáticas (STEM)}

\author{
Carmen María Fernández-García ${ }^{a}$ \\ Universidad de Oviedo, España \\ ORCID: http://orcid.org/0000-0001-6314-355X \\ SusANa TORÍO-López \\ Universidad de Oviedo, España \\ ORCID: http://orcid.org/0000-0001-5004-2338 \\ OMar García-Pérez \\ Universidad de Oviedo, España \\ ORCID: http://orcid.org/0000-0002-7001-2491 \\ Mercedes IndA-CARO \\ Universidad de Oviedo, España \\ ORCID: http://orcid.org/0000-0003-4752-3258
}

a Correspondence author. Email:

fernandezcarmen@uniovi.es

How to cite: Fernández-García. C. M., Torío-López, S., García-Pérez, O., \& Inda-Caro, M. (2019). Parental support, self-efficacy beliefs, outcome expectations and interests in Science, Technology, Engineering and Mathematics (STEM). Universitas Psychologica, 18(2), 1-15. https://doi.org/10.11144/Javeriana.upsy18-2.ps se

\begin{abstract}
The main objective of the paper will be to analyze the influence of parental academic expectations and gender stereotypes in secondary education students' self-efficacy beliefs, outcome expectations, and interests. 2364 students in their final year of Lower Secondary Education participated in the study in Spain. Data have been analyzed combining three procedures: descriptive analysis, comparison of means and structural equation modeling. The results indicate that boys perceive higher parental support than girls in technology and computing. Regarding gender stereotypes, boys perceive higher parental gender stereotypes than girls in technology/computing and science. In our sample, perceived parental support and gender stereotypes do not have a direct influence on outcome expectations and interest, however, self-efficacy beliefs do influence outcome expectations and interest.

Keywords

Vocational choices; gender; perceived parental support; STEM subjects; Lower Secondary Education.

\section{RESUMEN}

Nuestro objetivo en este trabajo es analizar el influjo de las expectativas parentales y estereotipos de género en las creencias de autoeficacia, resultados e intereses de los alumnos. La muestra se encuentra constituida por 2364 estudiantes en el último año de la Educación Secundaria Obligatoria en España. Para el análisis de los datos se han combinado análisis descriptivos, comparación de medias y modelos de ecuaciones estructurales. Los resultados indican que los chicos perciben más apoyo
\end{abstract}


parental que las chicas en tecnología e informática. En relación a los estereotipos de género, los chicos los perciben más, tanto en tecnología como en informática y ciencias. En nuestra muestra ni el apoyo parental ni los estereotipos de género tienen una influencia directa en los resultados e intereses. Sin embargo, las creencias de autoeficacia sí la tienen.

Palabras clave

elecciones vocacionales; género; apoyo parental; Asignaturas STEM; Educación Secundaria Obligatoria.

The lack of scientific vocation and low levels shown by many students in science, technology, engineering, and mathematics (STEM subjects) emerge as verifiable facts in recent research (Vázquez \& Manassero, 2009). Moreover, the promotion of research in these areas is among the priorities of most of the states and international organizations (Marbá \& Solsona, 2012). For this reason, several reports recently published by the Eurydice European Network on Education, for example, have focused attention on issues related to this priority (EACEA / Eurydice, 2010; EACEA \& Eurydice, 2012).

Men's and women's unequal preferences in STEM subjects is another point that can be systematically observed. Several studies have shown that female students were more interested in Biomedical areas or Humanities and Social Sciences than in the STEM field and that female students' self-efficacy beliefs about these subjects were lower than that of their male counterparts (Bleeker \& Jacobs, 2004; Fredricks \& Eccles, 2002; Inda, Rodríguez, \& Peña, 2013; Linver \& Davis-Kean, 2005; Peña-Menéndez, Torío-López, \& Fernández-García, 2006; Sáinz \& Eccles, 2012; Simpkins, Davis-Kean, \& Eccles, 2005). These results confirmed the influence of the gender variable. However, at the European level, it has been found that this trend is being reversed in several countries (EACEA/Eurydice 2010). Similar results have been found in the United States. So, Hyde, Lindberg, Linn, Ellis and Williams (2008), as well as Linver and DavisKean (2005) and Watt, Eccles and Durik, (2006) corroborated that there was no evidence of a gender difference favoring males in math tests.
Several reasons have been proposed to explain these gender differences, but we will focus on "perceived social support"; when people perceive that their social environment is supportive of their academic decisions and that no social barriers are preventing them from developing their vocational interests, they have strong beliefs about their ability to do well in the chosen vocational domain (Peña-Calvo, Inda-Caro, Rodríguez-Menéndez, \& FernándezGarcía, 2016). So, for example, Buday, Stake and Peterson (2012) found that social support contributed to men's and women's ability to envision themselves in a future science career. Besides, some studies indicated that there were gender differences because women perceived more social support and less social barriers than men for STEM studies (Lent et al., 2018; Lent et al., 2005; Navarro, Flores, \& Worthington, 2007), but in other studies the opposite argument has been demonstrated (Byars-Winston \& Fouad, 2008; Lindley, 2005).

\section{Gender and parental support}

Parents represent the major environmental influence on children's development and play a key role in the development of attitudes about academic disciplines. So, for example, Simpkins et al. (2005) found that maternal reports of their encouragement and parental provision of activity-related materials in STEM activities were higher for boys than for girls. However, in this study, there were no gender differences on fathers' encouragement.

In a cross-cultural study, Hanna (1994) found that in countries where there were no gender differences in math performance, boys and girls perceived they were receiving the same parental support, while in countries where boys performed better in mathematics, parental expectations for boys were higher. In a similar line, some studies have indicated that parents believe boys are better than girls in mathematics. So, for example, Ashby and Schoon (2010) concluded that boys' educational performance could benefit from raised parental aspirations. Bleeker and 
Jacobs (2004) also indicated that boys' mothers had higher expectations for their sons' success in math than girls' mothers in relation to their daughters' math achievement. Finally, Jacobs, Davis-Kean, Bleeker, Eccles, and Malanchuk (2005) found that parents provided more mathsupportive environments for their sons than for their daughters and they had higher perceptions of their sons' math abilities. Regarding science, Tenenbaum and Leaper (2003) found that girls' parents believed that their daughters had less interest in science than other parents whose children were males. Also, girls' parents believed that science was more difficult for their child than boys' parents did. Finally, this study found that there were some forms of teaching language that fathers used more with sons than with daughters in specific scientific tasks.

Other researches have studied the relation between mothers' and fathers' gender-related stereotype, child's gender and parents' beliefs about the child's abilities. In this sense, Tiedemann (2000) showed that parents perceived boys to be more competent in mathematics than girls. Likewise, parents' gender-related stereotypes interacted with the gender of the child and produced a direct effect path on parents' ability perception. So, parents with gender-related stereotypes assigned lower ability in math to their daughters than to their sons. Similarly, the study of Jacobs (1991) concluded that the influence of the child's gender on parents' beliefs about their child's mathematics abilities depended on their level of stereotyping. So, the research confirmed that parents with strong gender stereotypes had higher expectations regarding their sons' mathematical skills and achievement, even though girls had higher grades than boys at all grade levels in mathematics. In the longitudinal study of Räty and Kasanen (2007), the hypothesis that the gender-stereotypic views would moderate the parents' perceptions of their child's competence in mathematics received partial support. So, this expected interaction was not significant in the assessments made at the end of the child's third grade, but the gender stereotype predicted the assessments made by parents at the end of the fifth grade. Besides, this interaction between variables was limited to the group of parents that agreed with the gender stereotype.

The results obtained in qualitative studies do confirm the already mentioned conclusions. In the study of Sáinz, Palmén and García-Cuesta (2012) nearly 50\% of the high school students' parents who participated in the focus groups stated that the low presence of girls in STEM studies, could be explained because girls had lower aptitudes for these kinds of studies or the existence of certain professions which were more appropriate for males. Furthermore, some of the female students interviewed in the research conducted by Fouad et al. (2008) indicated that they received family messages in order to adjust their decisions to gender stereotypes.

\section{The role of parents in the development of gender-related self-efficacy beliefs and interest}

A large body of research has demonstrated that child's self-efficacy beliefs and interest are related with parents' evaluation about their competence (for a literature review about math subject see Gunderson, Ramirez, Levine, \& Beilock, 2012). In this sense, Wigfield et al. (1997) found that the associations of children's own competence beliefs to both their teachers' and their parents' ratings of their competence become stronger with age. Similarly, Tennenbaum and Leaper (2003) found that parents' beliefs predicted children's interest and self-efficacy in science.

Research has found that different parental expectations, stereotypes, and attributions about boys' and girls' academic success in STEM subjects influence students' self-efficacy beliefs and interest in these areas. Regarding the influence of parents in the development of interest, the study of Jacobs, Davis-Kean, Bleeker, Eccles and Malanchuk (2005) corroborated that when mothers had fewer gender-stereotyped views, girls and boys were more likely to be interested in mathematics, and when the father had a stereotypical view, girls' interest decreased 
while boys' interest increased. In a similar line, Jacobs, Chhin and Bleeker (2006) have verified that when parents expected that their daughters should choose "female" careers, these girls expressed similar expectations and made them effective over time. In sum, these authors suggested that decisions are taken within the context of gender-typed parental expectations. In the study of Bleeker and Jacobs (2004), female adolescents whose mothers reported low perception about their ability to succeed in maths careers were $66 \%$ less likely to choose STEM careers. However, mothers' perceptions had only a minimal influence on male adolescents' elections.

Parental expectations and gender stereotypes also influence self-efficacy beliefs. According to Tiedemann (2000), parents' beliefs about their child's abilities in math had a strong impact on the child's mathematical abilities perceptions. Likewise, parental expectations influenced girls' and boys' different beliefs about their math ability and performance, and these jointly determined their academic choices. So, for example in the study of Jacobs (1991) parents' beliefs about their child's mathematics abilities had a stronger impact on children's self-perception about their mathematics abilities than children's past performance in mathematics did. Bleeker and Jacobs (2004) found that if a mother had a low perception of her daughter's mathematical ability, the daughter would have low self-efficacy beliefs and would be less willing to pursue a STEM career. Similarly, Gniewosz, Eccles and Noack (2015) found that the competencyrelated information that the parents provided was related to gender differences in children's math ability self-concepts.

Qualitative studies have confirmed these ideas pointing out that some women who had chosen STEM studies recognized the relevance of their family to make the election and to persevere in it. They also admitted that the support had made them more resilient and made them gain confidence in their ability to succeed (Clegg \& Trayhurn, 1999; Erwin \& Maurutto, 1998; Scott \& Mallinckrodt, 2005; Zeldin, Britner \& Pajares, 2008; Zeldin \& Pajares, 2000). For these women being confident in their own capacities had been as important as to perceive family support.

\section{The present study}

The main objective of this paper is to analyze the influence of parental academic expectations and gender stereotypes in secondary education students' self-efficacy beliefs, outcome expectations, and interest. We hypothesized that: Hypothesis 1 (H1) Boys and girls would show differences in their perceptions about parental academic expectations and gender stereotypes; Hypothesis 2 (H2) The perception about fathers' and mothers' academic expectations would have a predictable value in students' self-efficacy beliefs, outcome expectations and interest; Hypothesis 3 (H3) The perception about fathers' and mothers' gender stereotypes would have a predictable value in students' self-efficacy beliefs, outcome expectations and interest (Figure 1).

\section{Figure 1}

Theoretical model proposed to analyze the influence of parental perceived expectations and stereotypes about Technology and Sciences on students' selfefficacy beliefs, outcome expectations, and interest.

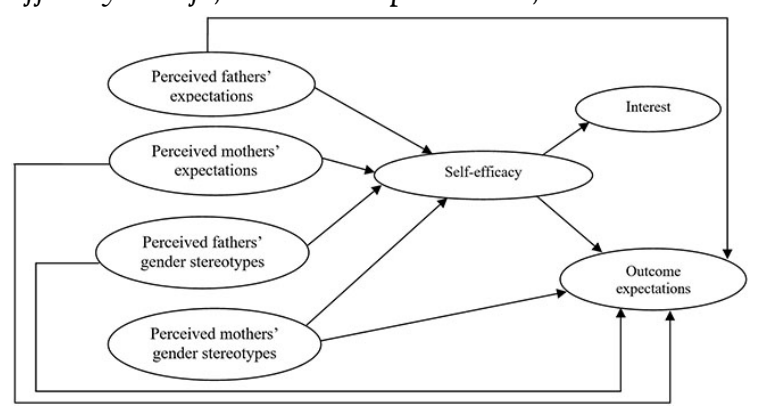

\section{Method}

\section{Sample}

The sample was made up of 2,364 students in their last year of compulsory education in the Principality of Asturias (Spain). The sampling technique used was a probability proportional to size (PPS). Gender, type of school and geographical origin were also considered in the 
selection of the sample. In the study, 1,197 women (50.7\%) and 1,162 men (49.2\%) - in 5 cases they did not indicate their gender answered the questionnaires. The students were aged 14 to $18(M=15.65$ and $S D=0.74)$. Analysis of age, by gender, revealed statistically significant differences $(F=10.8, p<0.01)$. In girls, the average age was $15.60(\mathrm{SD}=0.72)$ and in boys, 15.70 (SD = 0.76). On referring to geographical origin it is worth noting that $77.1 \%$ of the sample $(1,823$ students) attended schools located in the center/north of the region, which included highly populated cities; $10.2 \%$ (241 students) went to schools located in the coalfields zone, 3.8\% (91 students) lived in the eastern area of the region, and finally, $8.9 \%$ (209) lived in the west.

\section{Instruments}

Science and Technology Outcome Expectations Scale. It is a modified version of the Mathematics/ Science Outcome Expectations Scale (MSOES, Fouad, Smith, \& Enochs, 1997). This scale assesses high school students' beliefs about the potential consequences of studying science and technology subjects in high school $(1=$ strongly disagree to $6=$ strongly agree). Internal consistency $(\alpha)$ in the present sample was 0.95 , while Fouad and Smith's (1996) study yielded an $\alpha$ of 0.71, and Fouad et al. (1997) obtained an $\alpha$ of 0.70 .

Science and Technology Self-Efficacy Scale. This scale is a Spanish translation and adaptation of the Science Grade Self-Efficacy Scale (Britner \& Pajares, 2001; 2006). The scale consists of 3 items assessing high school students' confidence in their abilities to perform science and technology tasks successfully. Participants rated each item on a 6-point scale ranging from 1 (not confident at all) to 6 (completely confident). For the full sample, the scale yielded an $\alpha$ of 0.88 . Britner and Pajares (2006) found an $\alpha$ of 0.85 , and an earlier study by the same authors (Britner \& Pajares, 2001) yielded an $\alpha$ of 0.86 .

Science and Technology Interest Scale. This scale included 9 Likert-type items, and was an adaptation of the Engineering Fields Questionnaire (Lent et al., 2003). The original scale was intended for university students, but the research team adapted it to test adolescents' interest in science and technology activities. Participants rated each item on a 6-point scale ranging from 1 (very low interest) to 6 (very high interest). Reliability of this scale was 0.94. In Lent et al. (2003) this scale got an $\alpha$ of 0.83 , while in Lent et al. (2005) the $\alpha$ was 0.80 .

Sources of Science and Technology Self-Efficacy Scale. This is a Spanish translation and adaptation of the Sources of Science SelfEfficacy Scale (Britner \& Pajares, 2006). The scale consists of 59 items measuring the effects of mastery experience, vicarious experience, social persuasion, and psychological states (1 $=$ strongly disagree to $6=$ strongly agree). Britner and Pajares (2006) reported an $\alpha$ of 0.90 for mastery experience, 0.80 for vicarious experience, 0.88 for social persuasion, and 0.91 for emotional state. In our study, instrument yielded three subscales from factor analysis: perceived social supports, perceived social barriers, and emotional state. The mastery experience factor appears to be somewhat unclear; some items are found in the social persuasion factor and others in vicarious learning. The first subscale was the 21 items referring to "perceived social supports" $(\alpha=0.95$ in the present study), meaning the supports students have from significant others. The second subscale includes 11 items which measure variables that act as barriers to career development and is called "perceived social barriers" $(\alpha=0.85)$. The last subscale, "emotional state" with five items $(\alpha=$ 0.86), measures students' anxiety about science and technology subjects.

Four items from this scale which have been analyzed in detail conform one of the predictive variables: 'students' perception about parental academic expectations": "My father believes that I have high abilities to get good marks in technology/computing subjects"; "My mother believes that I have high abilities to get good marks in technology/computing subjects"; "My father believes that I have high abilities to get good marks in science subjects"; "My mother 
believes that I have high abilities to get good marks in science subjects".

Gender Roles Attitudes Scale. This scale consisted of 7 Likert-type items, also developed by the research team, for assessing the individual's gender stereotypes in relation to science and technology studies. Participants rated each item on a 6-point scale ranging from 1 $=$ strongly disagree to $6=$ strongly agree. Alpha coefficient in the present sample was 0.85. We evaluated the content validity using Lawshe's (1975) content validity ratio (CVR). Twentythree specialists, all with expert knowledge about gender differences in a range of scientific areas, took part in this evaluation. CVR values ranged from 0.82 to 1 .

Four items from this scale had a direct relation with the objectives of our investigation. They conform the second predictive variable: "students' perception about parental gender stereotypes": "My father believes that technology/computing is for boys", "My mother believes that technology/computing is for boys", "My father believes that science is for boys", "My mother believes that science is for boys".

\section{Procedure}

Data were collected during a regular school day by the research team. A total of 45 public and private educational institutions participated in the study. After a brief presentation in which the researchers described the purpose of the study, the students were asked to fill out a questionnaire which took about 30-45 minutes to complete. All of them participated voluntarily, and no parents withheld their consent. The validation of the questionnaire, which has been published in Inda-Caro, Rodríguez-Menéndez and PeñaCalvo (2016), was created taking into account several scales.

\section{Data analyses}

In order to study the relationship between students' gender and their perceptions of parental academic expectations and gender stereotypes about their performance in science and technology subjects, we carried out a descriptive analysis. We calculated chisquare $\left(\chi^{2}\right)$, contingency coefficient $(\mathrm{C})$, and standardized residuals $\left(z_{\text {residuals }}\right)(\mathrm{H} 1)$. Secondly, we made an analysis of variance to determine the effect sizes of students' gender on fathers' and mothers' beliefs about their abilities and performance in science and technology subjects (H1). Finally, we carried out structural equation modeling with IBM_AMOS22 software in order to test the theoretical model proposed in the state of the art. We aimed to assess the influence of students' perception about parental expectations and gender stereotypes on self-efficacy beliefs, outcome expectations and interest, considering the students' gender variable $(\mathrm{H} 2, \mathrm{H} 3)$.

\section{Results}

Missing Data

The percentage of missing cases in each of the variables of the study was analyzed. The percentage of missing data ranged from $1.9 \%$ to 4.7\%. Besides, differences between missing/nonmissing values cases in the predictor and criterion variables were studied. No significant differences were found in any of the variables $(p>0.05)$.

Boys' and girls' perceptions about parental academic expectations and gender stereotypes. Descriptive Analysis

When boys and girls were asked if their father thought they had the qualities for success in different subjects, and taking into consideration the gender variable, we found that the relationship was statistically significant for all subjects: technology $\left(\chi^{2}=135.442, p<0.001\right.$; $\mathrm{C}=0.237, p<0.001) ;$ science $\left(\chi^{2}=17.940, p\right.$ $<0.01 ; \mathrm{C}=0.088, p<0.01)$. Moreover, when they were asked about their mothers' opinion in the same question, similar conclusions were 
obtained: technology $\left(\chi^{2}=137.029, p<0.001\right.$; $\mathrm{C}=0.236, p<0.001)$; science $\left(\chi^{2}=29.027, p<\right.$ $0.001 ; C=0.111, p<0.001$ ) (Table 1).To sum up, boys and girls considered that their parents believed they had qualities for technology and science, but this conviction was always higher in boys, and these differences were more evident in technology than in science.

\section{Table 1}

Distribution of observed frequencies and standardized residuals

\begin{tabular}{|c|c|c|c|c|c|c|}
\hline \multirow{2}{*}{ Pereeption } & \multicolumn{2}{|c|}{$\begin{array}{c}\text { Girls } \\
(\mathrm{n}=1,197)\end{array}$} & \multicolumn{2}{|c|}{$\begin{array}{c}\text { Boys } \\
(\mathrm{n}=1,162)\end{array}$} & \multirow[t]{2}{*}{$\boldsymbol{F}$} & \multirow{2}{*}{$\begin{array}{l}\text { Effect } \\
\text { sizes } \\
\eta^{2}\end{array}$} \\
\hline & $M$ & $S D$ & $M$ & $S D$ & & \\
\hline $\begin{array}{l}\text { My father believes that I have high a } \\
\text { marks in technology/computing subj }\end{array}$ & 3.72 & 1.84 & 4.38 & 1.67 & $143.41^{\cdots}$ & 0.06 \\
\hline $\begin{array}{l}\text { My mother believes that I have high abilities to get good } \\
\text { marks in technology/ computing subjects }\end{array}$ & 3.77 & 1.78 & 4.49 & 1.6 & $144.12^{\cdots *}$ & 16 \\
\hline $\begin{array}{l}\text { My father believes that I have high abilities to get good } \\
\text { marks in science subjects }\end{array}$ & 3.96 & 1.91 & 4.08 & 1.77 & 3.22 & 0.6 \\
\hline $\begin{array}{l}\text { My mother believes that I have high abilities to get good } \\
\text { marks in science subjects }\end{array}$ & 4.09 & 1.85 & 4.21 & 1.68 & 2.27 & 0.001 \\
\hline hat & 83 & 1.56 & 2.60 & 1.91 & & 66 \\
\hline & & & & & & \\
\hline & & 1.33 & 2.40 & & & \\
\hline & 1.51 & 1.18 & 2.28 & 1.69 & $182.62^{\cdots}$ & \\
\hline
\end{tabular}

$\mathrm{G}=$ Girls; $\mathrm{B}=$ Boys DF = Definitely false; $\mathrm{MF}=$ Mostly false SF $=$ Slightly false $; \mathrm{AT}=$

Almost True; MT = Mostly true; DT = Definitely true. $Z_{r}=$ Standardized residuals; fo $=$ Observed

Frequency; fe $=$ Expected frequency. Positive values $Z_{r}=$ fo $>$ fe; Negative values $Z_{r}=$ fo $<$ fe

Two other items from the questionnaire allow us to enlarge upon this interpretation. Firstly, students were asked if their father/ mother believed that certain types of subjects were boys' or girls' "things". It is interesting that students' responses indicated a relationship between gender and this perception about fathers' belief for all subjects: technology $\left(\chi^{2}=145.957, p<\right.$ $0.001 ; \mathrm{C}=0.247, p<0.001)$; science $\left(\chi^{2}=\right.$ 183.692, $p<0.001 ; C=0.275, p<0.001)$. Mothers' answers confirmed the same relation: technology $\left(\chi^{2}=156.372, p<0.001 ; C=0.253\right.$, $p<0.001)$; science $\left(\chi^{2}=194.125, p=0 ; \mathrm{C}=\right.$ $0.280, p<0.001)$.

Again, boys tended to show a more stereotypical perception of their parents' opinion towards science: boys scored higher than expected in the items where they were enquired if their father/mother considered technology to be a male thing (result also present for science), whereas girls did not report such a high perception (Table 1).
Analysis of variance of boys' and girls' perceptions about parental academic expectations and gender stereotypes

The normality criterion was confirmed in all variables except "My father believes that science is for boys" and "My mother believes that science is for boys". These two items showed more than -1 and 1 skewness and kurtosis. On the other hand, the univariate homoscedasticity principle did not hold and Levene's test showed significance in all criterion variables $(p<0.001)$. However, the sample was large, and there was a balance among two groups; due to this fact, an analysis of variance and effect sizes was calculated with $\#^{2}$ to evaluate differences between girls and boys in the criterion variables. In order to confirm that previous analysis was adequate, Man-Whitney test was run with these two items with a non normal distribution.

As Table 2 shows, girls considered that their parents believed they had less ability than boys to perform well in technology subjects. Boys scored significantly higher $(p<0.001)$ in relation to fathers' and mothers' beliefs in all items except for parents' beliefs about their abilities to get good marks in science subjects, where there were no significant differences. We can confirm that in their daughters' and sons' opinions, fathers and mothers believed certain subjects seem more appropriate for boys than for girls, and where boys are supposed to have more capability than girls.

\section{Table 2}

Analyses of parental beliefs about students' abilities

\begin{tabular}{|c|c|c|c|c|c|c|}
\hline \multirow[t]{2}{*}{ Perception } & \multicolumn{2}{|c|}{$\begin{array}{c}\text { Girls } \\
(\mathrm{n}=1,197)\end{array}$} & \multicolumn{2}{|c|}{$\begin{array}{c}\text { Boys } \\
(\mathrm{n}=1,162)\end{array}$} & \multirow[t]{2}{*}{$F$} & \multirow{2}{*}{$\begin{array}{c}\text { Effect } \\
\text { sizes } \\
\eta^{2}\end{array}$} \\
\hline & & & & $S D$ & & \\
\hline $\begin{array}{l}\text { My father believes that I have high abilities to get } \\
\text { good marks in technology/computing subjects }\end{array}$ & 3.72 & 1.84 & 4.38 & 1.67 & $143.41^{\cdots \cdots}$ & 0.06 \\
\hline $\begin{array}{l}\text { My mother believes that I have high abilities to } \\
\text { get good marks in technology/ computing subjects }\end{array}$ & 3.77 & 1.78 & 4.49 & 1.6 & $144.12^{\cdots *}$ & 0.06 \\
\hline $\begin{array}{l}\text { My father believes that I have high abilities to get } \\
\text { good marks in science subjects }\end{array}$ & 3.96 & 1.91 & 4.08 & 1.77 & 3.22 & 0.001 \\
\hline $\begin{array}{l}\text { My mother believes that I have high abilities to } \\
\text { get good marks in science subjects }\end{array}$ & 4.09 & 1.85 & 4.21 & 1.68 & 2.27 & 0.001 \\
\hline $\begin{array}{l}\text { My father believes that technology/ computing is } \\
\text { for boys }\end{array}$ & 1.83 & 1.56 & 2.60 & 1.91 & $134.01^{\cdots}$ & 0.06 \\
\hline $\begin{array}{l}\text { My mother believes that technology/ computing is } \\
\text { for boys }\end{array}$ & 1.84 & 1.56 & 2.61 & 1.90 & $128.27^{\cdots}$ & 0.06 \\
\hline My father believes that science is for boys & 1.58 & 1.33 & 2.40 & 1.79 & $179.20^{\circ * \cdots}$ & 0.08 \\
\hline My mother believes that science is for boys & 1.51 & 1.18 & 2.28 & 1.69 & $182.62^{* \cdots}$ & 0.08 \\
\hline
\end{tabular}


Boys' and girls' perceptions about parental academic expectations and gender stereotypes and their influence on self-efficacy beliefs, interest, and outcome expectations

Prior to the path analysis, we examined Pearson correlations among factors, not only in girls but also in boys, as shown in Table III. This analysis was run employing maximum likelihood estimate method. Subsequently, diverse fit indices were evaluated; parsimony measures were calculated: $\chi^{2}$ value, CMIN/DF (minimum of discrepancy function/degrees of freedom), were considered adequate when showing values below 2. Concerning comparative indexes: CFI (Comparative fit index) and TLI (Tucker-Lewis index) values were set above 0.95 in order to get a good fit and, finally, RMSEA (Root mean square error of approximation) values were set lower than 0.08 for an acceptable fit.

\section{Table 3}

Pearson correlations, means and standard deviation in girls and boys

\begin{tabular}{|c|c|c|c|c|c|c|c|c|c|}
\hline Factor & 1 & 2 & 3 & 4 & 5 & 6 & 7 & $M$ & $S D$ \\
\hline 1. Self-efficacy & & $0.24 \cdots$ & $0.45^{\cdots *}$ & 0.01 & -0.01 & -0.03 & -0.04 & 3.78 & 1.57 \\
\hline $\begin{array}{l}\text { 2. Outcome } \\
\text { expectations }\end{array}$ & $0.25^{\cdots}$ & & $0.20^{\circ \cdots}$ & -0.02 & -0.03 & -0.03 & 0.04 & 3.93 & 1.26 \\
\hline 3.Interests & $0.46^{\cdots}$ & $0.17^{\cdots *}$ & & -0.01 & -0.01 & -0.03 & -0.04 & 2.17 & 1.38 \\
\hline $\begin{array}{l}\text { 4.Fathers' } \\
\text { Expectations }\end{array}$ & 0.02 & 0.05 & 0.01 & & $0.80^{\cdots \cdots}$ & -0.05 & $-0.11^{\cdots}$ & 3.76 & 1.62 \\
\hline $\begin{array}{l}\text { 5.Moth } \\
\text { Expect }\end{array}$ & -0.01 & 0.04 & -0.01 & $0.76^{\circ *}$ & & $-0.07 * *$ & $-0.07^{*}$ & 3.90 & 1.53 \\
\hline gender & 0.05 & -0.01 & 01 & $08^{*}$ & 0.02 & & $\cdots$ & 1.71 & 1.35 \\
\hline $\begin{array}{l}\text { 7.Mothers' gender } \\
\text { stereotypes }\end{array}$ & $0.06^{*}$ & -0.02 & 02 & 01 & -0.01 & $0.82^{\cdots \cdots}$ & & 1.67 & 1.27 \\
\hline$M$ & & & & & & & 2.4 & & \\
\hline$S D$ & & & 39 & 1.49 & 1.39 & 1.76 & 1.68 & & \\
\hline
\end{tabular}

Note. Girls' intercorrelations $(n=1197)$ are presented above the diagonal, and boys' intercorrelations $(n=1162)$ below it. Means and standard deviations are presented in the vertical columns for girls and in the horizontal rows for boys.

$$
\begin{gathered}
* p<0.05 \\
* * p<0.01 \\
* * * p<0.001
\end{gathered}
$$

Firstly, we wanted to launch the measurement model with the full sample to determine the fit to theoretical model proposed. The model showed in Figure 1 was tested, and the fit indexes were $\left(\chi^{2}=15.71 ; d f=5, p<0.01\right)$, CMIN/ $D F=3.14 ; C F I=0.99 ;$ TLI $=0.99$, RMSEA $=0.03$ ). All indexes showed good values except for CMIN/DF, and the weights of students' perception about parental expectations and gender stereotypes on outcomes expectations were almost zero or zero. Considering this finding, we also tried a more parsimonious model, without these paths. The resulting model was Model 0. As it can be seen in Table 4 the fit indexes were very optimal. Afterwards we tested the model for girls (Model 1) and for boys (Model 2). The measurement model fitted both for girls and boys (Table 4). A multiplegroup analysis was also carried out to explore the model fit (Figure 2). Table 4 presents the fit indices for these alternative models taking into consideration the recommendation made by experts to report several indices of model fit (Hoyle, 1995). Model 3 depicted a good fit for gender variable (Model 3). Furthermore, the three models were considered to test the structural invariance of the model. The first model (constrained weight model) considered the same loads for girls and boys (Model 4) and revealed a very good fit. The comparison of model 3 and model 4 , using $\chi^{2}$ differences test, indicated that there were no differences $\left(\Delta \chi^{2}=\right.$ $8.05, \mathrm{p}=0.25)$. On the other hand, two other models were tested, one of them considering the intercepts equality (Model 5) and another one seeing the residual variances equality. These last models showed worse fit than Model 3. In addition, there were significant differences among them (Table 4). These analyses showed that structural invariance could not be observed, as long as significant differences were found between Model 3 and Model 5 and Model 6 . However, the best fit was obtained for Model 3, in which there was no constrainment.

\section{Table 4}

Fit indices for girls, boys and constrained models

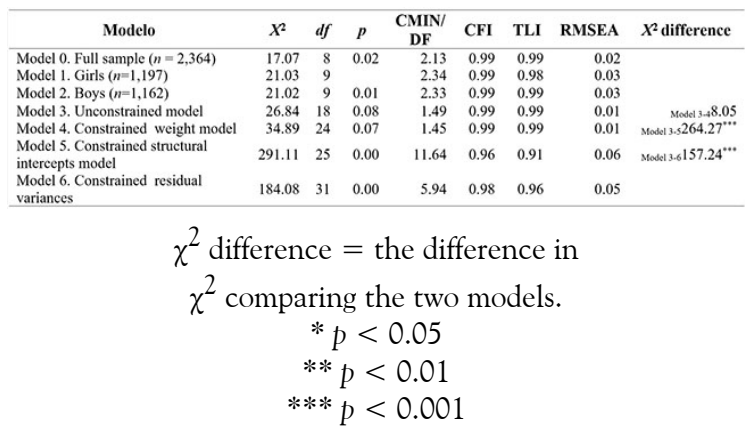

| Universitas Psychologica | V. I8 | No. 2 | 2019 | 
To start with, we must highlight that although the coefficients of the predictive variables (students' perceptions about parental academic expectations and gender stereotypes) were not significant, it is worth considering the sign of the path. It can be stated that when a student perceived that his or her father did not show gender stereotypes, self-efficacy beliefs tended

to have a positive tendency. If we focus on mothers' influence, we obtained that when girls and boys perceived gender stereotypes in their mothers, their self-efficacy beliefs also showed the same tendency. Moreover, self-efficacy beliefs tended to rise when boys and girls perceived good academic expectations in their fathers. On the other hand, when boys and girls perceived mothers' positive academic expectations, selfefficacy beliefs seemed to have a negative tendency.

Figure 2

Path model depicting influence of perceived family expectations and gender stereotypes

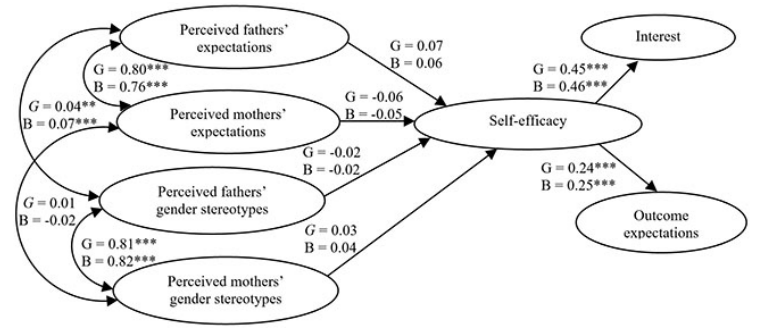

Note. Multiple-group path analysis by gender. Standardized weights are the paths coefficients. For girls, $R^{2}$ self-efficacy $=0.4 \% ; R^{2}$ Outcome expectations $=8 \%$ and $R^{2}$ interests $=$ $22 \%$. For boys, $R^{2}$ self-efficacy $=0.6 \%$; $R^{2}$ Outcome expectations $=9 \%$ and $R^{2}$ interests $=22 \%$. $\mathrm{G}=$ Girls; $\mathrm{B}=$ Boys $(\mathrm{n}=$ $2,359) * p<0.05 * *<<0.01 * * * p<0.001$

As shown in Figure 2, the complementary relation between fathers' academic expectations and gender stereotypes, and mother's academic expectations and gender stereotypes need to be reviewed since the correlations were not high. Despite this, it should be born in mind that the sign of the correlation between the perception of mothers' academic expectations and gender stereotypes in boys was negative: when a boy perceived gender stereotypes in his mother, the perception of good academic expectations (good marks) seemed to be affected and decreased. A relation between the perception of parental gender stereotypes in boys and girls could be evidenced. This may reflect a coherence in the educational perspective of the couple in gender issues. The same situation could be shown in the academic expectations: when a boy or a girl perceived high parental expectations in science and technology, they perceived them simultaneously in their fathers and mothers.

As regards the relationship between boys' and girls' perceptions about parental academic expectations and gender stereotypes, the research has found little influence on self-efficacy beliefs (the percentage of explained variance was low). In contrast, self-efficacy beliefs had a determinant influence on students' interest and outcome expectations in science and technology.

\section{Discussion}

It has been shown that parents have different expectations and aspirations regarding girls' and boys' capabilities and performance. Regarding $\mathrm{H} 1$, our results complement the analysis of other studies which found that mothers and fathers had different expectations about their sons' and daughters' skills and performance in STEM subjects (Bleeker \& Jacobs, 2004; Jacobs et al., 2005; Tennenbaum \& Leaper, 2003). In our study, girls scored lower than boys in perceived parental academic expectations in technology and science subjects, so boys perceived their parents had more faith than the girls' ones in their chances of success in these fields. These results contrast with several investigations which have shown that girls perceived more careerrelated support and positive feedback from their parents (Dietrich \& Kracke, 2009; Noack, Kracke, Gniewosz, \& Dietrich, 2010). It should be noted that the research developed by Dietrich and Kracke (2009) and Noack et al. (2010) was developed in Germany where tracking starts earlier than in the Spanish education system. This fact means that when participating in the current research, students in Spain were in the 
exact moment of deciding if they would continue in the academic or vocational track.

Further research is needed to determine why this sense of insecurity seems to be more intense in girls and why they perceive less support from their parents. Nevertheless, educational authorities in Spain are promoting educational programs to support girls in STEM subjects, starting in early stages of their education e.g., Primary Education (Ministerio de Educación y Formación Profesional de España, 2019). In our study, gender differences were more significant in technology than in science. In fact, the standardized residuals were lower in science than in the other subjects.

It seems that boys and girls perceived parental gender stereotypes referring to general facts (certain subjects are more suitable for boys), but they do not appear to perceive them with the same intensity when they are asked about their ability to obtain good grades in technology and science. In our study, boys perceived more parental gender stereotypes than girls and these stereotypes were higher in technology than in science. These results complement the conclusions of other studies which found that parents' gender-related stereotypes influence parents' perception of their children abilities (Tiedemann, 2000; Jacobs, 1991; Räty \& Kasanen, 2007).

In contrast with other studies in which parental expectations and gender stereotypes influenced self-efficacy beliefs (Bleeker \& Jacobs, 2004; Gniewosz et al., 2015; Jacobs, 1991; Tiedemann, 2000), in our research students' perception about parental academic expectations and gender stereotypes did not have an statistical significant relationship with their self-efficacy beliefs $(\mathrm{H} 2, \mathrm{H} 3)$ in the SEM analysis. One possible explanation may be that the lack of variability in scores assessing gender-role attitudes, may have contributed to the lack of validity of this variable. Moreover, the cited studies considered more factors (e.g., work and social expectations), which might be influencing outcome expectations and not only students' achievement. The same point could be observed converning gender stereotypes, as they considered teachers' and mates' stereotypes and not only parental ones.

Although the weights of the coefficients were not significant, their sign showed the direction of the influence of students perceived parental academic expectations and gender stereotypes. Furthermore, we could conclude that the construct 'parental support' might be formed by numerous variables and 'academic expectations' did not seem to be the most determinant one. It is also worth noting the differences observed in parental gender stereotypes: we can hypothesize that when the father showed gender stereotypes, self-efficacy beliefs might tend to be lower. However, when these stereotypes were observed in the mother, self-efficacy beliefs might have the opposite tendency; when students perceived high academic expectations in their father self-efficacy beliefs tended to increase, but if they observed them in their mother they tended to decrease.

Moreover, in our research perceived parental academic expectations and gender stereotypes did not have a direct influence on outcome expectations and interest $(\mathrm{H} 2, \mathrm{H} 3)$, showing a great contrast with the conclusions obtained by other researches (Bleeker \& Jacobs, 2004; Jacobs et al., 2005; Jacobs et al., 2006) and with our previous study in which perceived social support and perceived social barriers had an influence on technology outcome expectations and technology interest (Inda-Caro et al., 2016). This fact may be giving us information about the need to identify other supports and barriers outside the family, which may have more influence in the Spanish context and which could explain why parents are not so determinant. Fouad et al. (2010) explained that the majority of the research had focused thus far on the individual variables, whereas the study of the effect of other environmental variables remains scarce, so this study represents an attempt to follow their recommendations exploring the parental dimension of these contextual variables in more detail. The findings of SEM analyses revealed that it is necessary to consider the forward analysis in order to explain the differences found in the proposed model. This research illustrated how students' perception of 
parental expectations and gender stereotypes regarding STEM studies could be related to students' gender. Although the coefficients of the model were the same for boys and girls, caution is needed in order to generalize these results to the whole population: the mean values on population could be different, and the factors to improve the model could also be different for girls and boys. Moreover, this hypothesis was supported by the ANOVA results, which have revealed differences in students' perceptions about parental expectations and gender stereotypes. Also, the low explained variances of the model pointed out the presence of other supports and barriers different from parental expectations and gender stereotypes, which influence the core variables of the SCCT model.

To sum up, the educational system and other social institutions still perceive STEM subjects as "male domains" leading students to internalize norms, values and social roles that influence the development of their vocational choices (Sáinz \& Eccles, 2012). In this sense, it is necessary to design and implement vocational programs and to develop classroom intervention techniques that examine and discuss with girls the reasons for their lack of presence in STEM studies. These programs should evaluate the social and personal barriers that prevent more women from studying these academic disciplines, and should also help girls to analyse and assess a broader range of academic and career options, to identify and clarify their potential career patterns, and to reflect on the reasons for the choices they make and do not make. This kind of initiatives may encourage an "orientation towards meanings", which may explain their expectations and vocational self-clarity (Duffy, Douglass, Autin, \& Allan, 2014).

\section{Limitations}

All the data from this research have been obtained from boys' and girls' answers. We are aware of the need to put these in context with fathers' and mothers' real beliefs in the qualitative phase of the investigation. In the future, it would be important to replicate the study with other samples in more ethnically and diverse geographical contexts, in order to explore if the results maintain the intensity or the interesting tendency shown in perceived academic expectations and gender stereotypes.

Finally, the cross-sectional nature of this research is a methodological limitation. The study can indicate statistical relationships between particular variables but cannot support causal inferences. It would also be important to analyze if there might be previous variables which could be configuring students' perceptions and which have not been considered in the present study.

\section{Acknowledgements}

This article is based on work supported by the Spanish Ministry of Economy and Competitiveness from 2011 to 2013 (EDU2010-17233). We gratefully acknowledge the assistance of R. W. Lent, who sent us the scales used in this study.

\section{References}

Ashby, J. S., \& Schoon, I. (2010). Career success: the role of teenage career aspirations, ambition value and gender in predicting adult social status and earnings. Journal of Vocational Behavior, 77(3), 350-360. https:/ /doi.org/10.1016/j.jvb.2010.06.006

Bleeker, M. M., \& Jacobs, J. (2004). Achievement in math and science: do mothers' beliefs matter 12 years later? Journal of Educational Psychology, 96(1), 97-109. https://doi.org/1 0.1037/0022-0663.96.1.97

Britner, G., \& Pajares, F. (2001). Self-efficacy beliefs, motivation, race, and gender in middle school science. Journal of Women and Minorities in Science and Engineering, 7(4), 269-283. https://doi.org/10.1615/JWomen MinorScienEng.v7.i4.10

Britner, S. L., \& Pajares, F. (2006). Sources of Science Self-Efficacy Beliefs of Middle 
School Students. Journal of Research in Science Teaching, 43(5), 485-499. https://do i.org/10.1002/tea.20131

Buday, S. K., Stake, J., \& Peterson, Z. (2012). Gender and the choice of a science career: the impact of social support and possible selves. Sex Roles: A Journal of Research, 66(3-4), 197-209. https://doi.org/10.1007/s 11199-011-0015-4

Byars-Winston, A., \& Fouad, N. A. (2008). Math and science social cognitive variables in college students. Contributions of contextual factors in predicting goals. Journal of Career Assessment, 16(4), 425-440. https://doi.org/10.1177/10690727 08318901

Clegg, S., \& Trayhurn, D. (1999). Gender and computing: not the same old problem. British Educational Research Journal, 26(1), 75-89. https://doi.org/10.1080/0141192001 09525

Dietrich, J., \& Kracke, B. (2009). Career specific parental behaviors in adolescents' development. Journal of Vocational Behavior, 75(2), 109-119. https://doi.org/10.1016/j.jv b.2009.03.005

Duffy, R. D., Douglass, R. P., Autin, K. L., \& Allan, B. A. (2014). Examining predictors and outcomes of a career calling among undergraduate students. Journal of Vocational Behavior, 85(3), 309-318. https:/ /doi.org/10.1016/j.jvb.2014.08.009

EACEA/Eurydice. (2010). Gender Differences in Educational Outcomes: Study on the Measures Taken and the Current Situation in Europe. Brussels: Eurydice. Retrieved from http://ea cea.ec.europa.eu/education/eurydice/docu ments/thematic reports/120EN.pdf

EACEA/Eurydice. (2012). Developing Key Competences at School in Europe: Challenges and Opportunities for Policy. Eurydice Report. Luxembourg: Publications Office of the European Union. Retrieved from http://eac ea.ec.europa.eu/education/eurydice/docum ents/thematic_reports/145EN.pdf

Erwin, L., \& Maurutto, P. (1998). Beyond access: considering gender deficits in science education. Gender and Education, 10(1),
51-69. https://doi.org/10.1080/0954025982 1096

Fouad, N. A., \& Smith, P. L. (1996). A test of a social cognitive model for middle school students: math and science. Journal of Counseling Psychology, 43(3), 338-346. ht tps://doi.org//10.1037/0022-0167.43.3.338

Fouad, F., Smith, P. L., \& Enochs, I. (1997). Reliability and validity evidence for the middle school self-efficacy scale. Measurement and Evaluation in Counseling and Development, 30(1), 17-31. https://doi. org/10.1037/t20421-000

Fouad, N., Kantamneni, N., Smothers, M., Chen, Y., Fitzpatrick, M., \& Terry, S. (2008). Asian American career development: a qualitative analysis. Journal of Vocational Behavior, 72 (1), 43-59. https://doi.org/10.1 016/j.jvb.2007.10.002

Fouad, N. A., Hackett, G., Smith, P. L., Kantamneni, N., Fitzpatrick, M., Haag, S., $\&$ Spencer, D. (2010). Barriers and supports for continuing in mathematics and science: Gender and educational level differences. Journal of Vocational Behavior, 77, 361-373. https://doi.org/10.1016/j.jvb.2010.06.004

Fredricks, J. A., \& Eccles, J. S. (2002). Children's competence and value beliefs from childhood through adolescence: growth trajectories in two male-sex-typed domains. Developmental Psychology, 38(4), 519-533. https://doi.org/10.1037/0012-164 9.38.4.519

Gniewosz, B., Eccles, J., \& Noack, P. (2015). Early adolescents' development of academic selfconcept and intrinsic task value: The role of contextual feedback. Journal of Research on Adolescence, 25(3), 459-473. https://doi. org/10.1111/jora. 12140

Gunderson, E.A.; Ramirez, G., Levine, S., \& Beilock, S. (2012). The role of parents and teachers in the development of genderrelated math attitudes. Sex Roles, 66(3-4), 153-166. https://doi.org/10.1007/s11199-0 $11-9996-2$

Hanna, G. (1994). Cross-cultural gender differences in mathematics education. International Journal of Educational Research, 
21(4), 417-426. https://doi.org/10.1016/S0 883-0355(06)80030-3

Hyde, J., Lindberg, S. M., Linn, M., Ellis, A., $\&$ Williams, C. (2008). Gender similarities characterize math performance. Science, 321 (5888), 494-496. https://doi.org/10.112 6/science. 1160364

Hoyle, R. (1995). Structural equation modeling. Concepts, Issues and Applications. London: Sage.

Inda, M., Rodríguez, C., \& Peña, J. V. (2013). Gender differences in applying social cognitive career theory in engineering students. Journal of Vocational Behavior, 83(3), 346-365. https://doi.org/10.1016/j.jv b.2013.06.010

Inda-Caro, M., Rodríguez-Menéndez, C., \& Peña-Calvo, J. V. (2016). Spanish High School Students' interests in Technology: applying Social Cognitive Career Theory. Journal of Career Development, 43(4), 291-307. https://doi.org/10.1177/08948453 15599253

Jacobs, J. E. (1991). Influence of gender stereotypes on parent and child mathematics attitudes. Journal of Educational Psychology, 83(4), 518-527. htt ps://doi.org/10.1037/0022-0663.83.4.518

Jacobs, J.E., Chhin, C.S. \& Bleeker, M.M. (2006). Enduring links: parent's expectations and their young adult children's gender-typed occupational choices. Educational Research and Evaluation, 12(4), 395-407. doi: 10.1080/13803610600765851

Jacobs, J. E., Davis-Kean, P., Bleeker, M., Eccles, J. S. \& Malanchuk, O. (2005). "I can, but I don't want to". The impact of parents, interests and activities on gender differences in math. In A. M. Gallagher \& J. C. Kaufmank. (Eds.), Gender differences in mathematics. An integrative psychological approach (pp. 246-263). New York, NY: Cambridge University Press.

Lawshe, C. H. (1975). A quantitative approach to content validity. Personnel Psychology, 28, 563-575. https://doi.org/10.1111/j.1744-65 70.1975.tb01393.x
Lent, R. W., Brown, S. D., Schmidt, J., Brenner, B., Lyons, H., \& Treistman, D. (2003). Relation of contextual supports and barriers to choice behavior in engineering majors: test of alternative social cognitive models. Journal of Counseling Psychology, 50(4), 458-465. https://doi.org/10.1037/0022-016 7.50.4.458

Lent, R.W., Brown, S.D., Sheu, H., Schmidt, J., Brenner, B. R., Gloster, C.S., Wilkins, G., ... Treistman, D. (2005). Social cognitive predictors of academic interests and goals in engineering: utility for women and students at historically black universities. Journal of Counseling Psychology, 52 (1), 84-92. https:/ /doi.org/10.1037/0022-0167.52.1.84

Lent, R. W., Sheu, H, Miller, M., Cusick, M., Penn, L., \& Truong, N. (2018). Predictors of science, technology, engineering, and mathematics choice options: a metaanalytic path analysis of the socialcognitive choice model by gender and race/ ethnicity. Journal of Counseling Psychology, 65(1), 17-35. https://doi.org/10.1037/cou0 000243

Lindley, L. D. (2005). Perceived barriers to career development in the context of social cognitive career theory. Journal of Career Assessment, 13(3), 271-287. https://doi.org $/ 10.1177 / 1069072705274953$

Linver, M. R., \& Davis-Kean, P. E. (2005). The slippery slope: what predicts math grades in middle and high school? New Directions for Child and Adolescent Development, 110, 49-64. https://doi.org/10.1002/cd.149

Marbá, A., \& Solsona, N. (2012). Identificación e interpretación y las posibles desigualdades formativas en ciencias de chicos y chicas en la educación obligatoria y el bachillerato [Identification and interpretation of possible differences in science education between boys and girls in compulsory secondary education and upper secondary education]. Cultura y educación, 24(3), 289-303. https://doi.org/10.1174/11356401 2802845659 
Ministerio de Educación y Formación Profesional de España. (2019). Scientix. Retrieved from http://educalab.es/proyectos/scientix

Navarro, R., Flores, L., \& Worthington, R. (2007). Mexican American middle school students' goal intentions in mathematics and science: a test of social cognitive career theory. Journal of Counseling Psychology, 54(3), 320-335. https://doi.org/10.1037/00 22-0167.54.3.320

Noack, P., Kracke, B., Gniewosz, B., \& Dietrich, J. (2010). Parental and school effects on students' occupational exploration: a longitudinal and multilevel analysis. Journal of Vocational Behavior, 77(1), 50-57. https:/ /doi.org/10.1016/j.jvb.2010.02.006

Peña-Calvo, J. V., Inda-Caro, M., RodríguezMenéndez, C., \& Fernández-García, C. M. (2016). Perceived supports and barriers for career development for second-year STEM students. Journal of Engineering Education, 105(2), 341-365. https://doi.org/10.1002/je e.20115

Räty, H., \& Kasanen, K. (2007). Gendered views of ability in parents' perceptions of their children's academic competencies. Sex Roles, 56(1-2), 117-124. https://doi.org/10. 1007/s11199-006-9153-5

Rodríguez-Menéndez, M. C., Torío-López, S., \& Fernández-García, C.M. (2006). El impacto del género en las elecciones académicas de los estudiantes que finalizan la ESO. Revista Española de Orientación y Psicopedagogía, 17(2), 239-260. https://doi.org/10.5944/re op.vol.17.num.2.2006.11351

Sáinz, M., \& Eccles, J. (2012). Self - concept of computer and math ability: gender implications across time and within ICT studies. Journal of Vocational Behavior, 80 (2), 486-499. https://doi.org/10.1016/j.jv b.2011.08.005

Sáinz, M., Palmén, R., \& García-Cuesta, S. (2012). Parental and secondary school teachers' perceptions of ICT and their role in the choice of studies. Sex Roles, 66(3-4), 235-249. https://doi.org/10.1007/s11199-0 11-0055-9.
Scott, A. B., \& Mallinckrodt, B. (2005). Parental emotional support, science self-efficacy, and choice of science major in undergraduate women. The Career Development Quarterly, 53(3), 263-273. https://doi.org/10.1002/j.2161-00 45.2005.tb00995.x

Simpkins, S., Davis-Kean, P., \& Eccles, J. (2005). Parents' socializing behaviour and children's participation in math, science and computer out-of-school activities. Applied Developmental Science, 9(1), 14-30. https://doi.org/10.1207/s15324 80 xads0901 3

Tennenbaum, $\bar{H} ., \quad \&$ Leaper, C. (2003). Parent-child conversations about science: the socialization of gender inequities? Developmental Psychology, 39(1), 34-47. htt ps://doi.org/10.1037/0012-1649.39.1.34

Tiedemann, J. (2000). Parent's gender stereotypes and teacher's beliefs as predictors of children's concept of their mathematical ability in elementary school. Journal of Educational Psychology, 92(1), 144-151. https://doi.org/10.1037/0022-066 3.92.1.144

Vázquez, A., \& Manassero, M. A. (2009). Patrones actitudinales de la vocación científica y tecnológica en chicas y chicos de Secundaria [Attitudinal patterns of scientific and technological talent in girls and boys in Secondary Education]. Revista Iberoamericana de Educación, 50(4), 1-12. h ttps://doi.org/10.35362/rie5041879

Watt, H.; Eccles, J., \& Durik, A. (2006). The leaky mathematics pipeline for girls. A motivational analysis of high school enrolments in Australia and the USA. Equal Opportunities International, 25(8), 642-659. https://doi.org/10.1108/02610150 610719119

Wigfield, A., Eccles, J., Yoon, K., Harold, R., Arbreton, A., Freedman-Doan, C., \& Blumenfeld, P. (1997). Change in children's competence beliefs and subjective task values across the elementary school years: a 3-Year study. Journal of Educational 
Psychology, 89(3), 451-469. https://doi.org/ 10.1037/0022-0663.89.3.451

Zeldin, A. L., Britner, S. L., \& Pajares, F. (2008). A comparative study of the self-efficacy beliefs of successful men and women in mathematics, science and technology careers. Journal of Research in Science Teaching, 45(9), 1036-1058. https://doi.org/ $10.1002 /$ tea.20195

Zeldin, A. L., \& Pajares, F. (2000). Against the odds: self-efficacy beliefs of women in mathematical, scientific and technological careers. American Educational Research Journal, 37(1), 215-246. https://doi.org/10. 3102/0002831203700121

\section{Notes}

* Research article. 